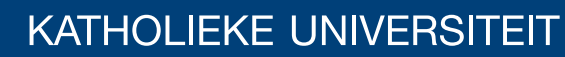 \\ LEUVEN
}

\section{Faculty of Economics and Applied Economics}

Corporate governance and performance: Controlling for sample selection bias and endogeneity

Annelies Renders and Ann Gaeremynck

DEPARTMENT OF ACCOUNTANCY, FINANCE AND INSURANCE (AFI) 


\title{
Corporate Governance and Performance: Controlling for Sample Selection Bias and Endogeneity
}

\author{
Annelies Renders ${ }^{*}$, Ann Gaeremynck \\ K.U.Leuven \\ Department of Accounting, Finance and Issurance
}

\begin{abstract}
Studies investigating the relation between corporate governance and performance find only weak evidence that corporate governance affects performance. One reason could be that these studies fail to control properly for sample selection bias and endogeneity. Without controlling for these problems, the relation between corporate governance and performance is not inferred correctly. With this study, we provide evidence on the influence of endogeneity and sample selection bias on the coefficient of corporate governance.

We use panel data for the FTSE Eurotop 300 companies over 5 years, from 1999 to 2003. We find that using a sample of the 300 largest companies induces selection bias in the results. Furthermore, the results show that an endogeneity problem is present. This endogeneity problem is caused by a negative reverse causality between performance and corporate governance. After controlling for both problems the coefficient on corporate governance increases and becomes highly significant, where it is insignificant when we use OLS. The results also show that controlling for both problems at the same time is important as by controlling for just one of these problems the bias is only partially reduced. Furthermore, we find that both problems have an equally large impact on the bias in the coefficient. Overall, our findings indicate that the lack of significant results in prior studies is due to not controlling properly for sample selection bias and endogeneity.
\end{abstract}

Keywords: corporate governance, endogeneity, firm performance, firm value, sample selection bias

\footnotetext{
${ }^{*}$ Corresponding author. Department of Accounting, Finance and Insurance, Catholic University of Leuven, Naamsestraat 69, B-3000 Leuven, Belgium. Phone: +32-16-326776; fax: +32-16-326732.

E-mail address: annelies.renders@econ.kuleuven.be (A. Renders).

\# We thank the FWO for the financial support (FWO-project G.0244.02) and Deminor Rating for providing the corporate governance ratings. We gratefully acknowledge the help of Christophe Croux with the econometric model. We thank Philip Joos for his discussion of the paper at the $5^{\text {th }}$ Research Seminar in Accounting on October 26, 2005 in Rotterdam. This paper has also benefited from the comments of Wayne Landsman, Roger Meuwissen, and Erik Peek. We thank Glyn Winterbotham, Wayne Thomas, Ole-Kristian Hope and the other participants of the International Accounting Section Mid-Year Conference in LA (January 12-14, 2006) for their comments and suggestions. Finally, we are grateful for the comments of Mark Lang and the other participants of the accounting seminar of the Kenan-Flagler Business School in Chapel Hill on 8 March 2006.
} 


\section{Introduction}

Corporate governance has recently received a lot of attention from policy makers and academic researchers alike and the number of empirical studies on corporate governance has grown considerably in the accounting and finance literature. Studies typically examine whether corporate governance structures affect or constrain executive behaviour or influence organizational performance. However, these studies fail to find persuasive evidence that corporate governance affects company performance or value (Bauer et al., 2003; Bhagat and Black, 2002; Black et al., 2005a; Larcker et al., 2004).

The lack of significant results in prior studies may be attributed to not effectively controlling for sample selection bias and endogeneity. Corporate governance studies face econometric problems such as measurement error, omitted variables, sample selection bias and endogeneity. For instance, regarding sample selection, most studies only analyze the largest listed companies.

The purpose of this study is to investigate the influence of sample selection bias and endogeneity on the coefficient of corporate governance and to arrive at a less biased coefficient from which more firm conclusions can be drawn regarding the importance of corporate governance for company performance. ${ }^{1}$

The contributions of this paper can be situated in two areas, namely with regard to the statistical modelling and with regard to the data. We use a multi-stage model in which we simultaneously control for both sample selection bias and endogeneity. Although some prior studies have tried to control for endogeneity, none of them has tackled the problem of selection bias. This multi-stage model is easy to implement and can be used in future studies. We also show how controlling for neither or just one of these problems affects the coefficient of corporate governance and compare the results with these of our multi-stage model.

With regard to the data, we use panel data over 5 years. The use of panel data is rare in governance studies because of the lack of corporate governance data over time (Börsch-Supan and Köke, 2002). We also concentrate on European companies. Only few studies have investigated so far the link between corporate governance and performance in Europe (e.g. Bauer et al., 2003; Drobetz et al., 2003). In contrast to the US, compliance with corporate governance codes is not mandatory in Europe but merely recommended and encouraged through the use of the "comply-or-explain" principle. ${ }^{2}$ In controlling for endogeneity, we

\footnotetext{
${ }^{1}$ The focus of this study is on controlling for sample selection bias and endogeneity. With regard to the problems of measurement error and omitted variables, we rely on prior studies and use an extensive set of dependent and control variables.

${ }^{2}$ Companies have to comply with the corporate governance codes or explain why they deviate from it.
} 
exploit the fact that we have data across different countries by introducing a country-level instrument. Finally, as corporate governance studies typically examine both accounting and market performance measures, such as return on assets, Tobin's q and the market-to-sales ratio, we use an extensive set of performance measures, comprehending both accounting performance measures and measures of firm value.

Our results show that sample selection bias is present in our data for both market and accounting measures of performance. We also find that there is an endogeneity problem for all performance measures. The results indicate that when performance worsens, management tries to improve corporate governance. This strategy works as we find that corporate governance has a highly significant impact on corporate profitability and value after controlling for endogeneity and selection bias. With regard to the size of the bias, our results show that both selection bias and endogeneity have an equally large influence on the coefficient of corporate governance and that controlling for both these problems leads to the largest increase in the coefficient. This indicates that controlling for one of these problems reduces the bias only partially. Overall, our findings suggest that future studies on corporate governance and performance should control for both sample selection bias and endogeneity as the coefficient of corporate governance is severely underestimated when these problems are not controlled for.

The remainder of this paper is structured as follows. First, we give an overview of the existing literature. Next, we define the model and the variables and outline the sample used. In the following sections, we discuss the results and present some robustness tests. Finally, the main findings of this paper are summarized and some implications and limitations are discussed.

\section{Literature review}

The separation between the ownership and control of a company gives rise to agency problems as managers tend to pursue their own interests instead of those of the shareholders. Corporate governance can reduce these agency problems by installing mechanisms to monitor managers. This should lead on the one hand to a higher operating performance as managers are stimulated to invest in projects with a positive net present value (Shleifer and Vishny, 1997) and on the other hand to an increase in firm value as investors realise that more of the firm's cash flows will flow back to them.

A number of studies investigate the relation between corporate governance and firm value or firm performance empirically and find mixed results. For emerging countries, the results 
show that corporate governance has a significant positive relation with firm value (Black, 2001; Black et al., 2005a; Durnev and Kim, 2005; Klapper and Love; 2004), but for profitability measures the results are not consistent (Black et al., 2005a; Klapper and Love, 2004). In developed countries, the results are more conflicting. Larcker et al. (2004) finds only weak evidence of a relation between corporate governance and firm value for US companies, while Gompers et al. (2001) documents a strong correlation between takeover measures and Tobin's Q. The results of Bauer et al. (2003) show for a sample of FTSE Eurotop 300 companies almost no significant relation between corporate governance and either market or accounting performance measures, with even some hints of a negative relation. Contrarily, Drobetz et al. (2003) finds a positive impact of a self-constructed corporate governance index on firm value for German companies. Finally, studies in Australia fail to find evidence that corporate governance is related with either operating performance (Linden and Matolcsy, 2004) or market value (Matolcsy et al., 2004).

The lack of significant results in prior studies could be due to sample selection bias. None of the prior studies test or correct for sample selection bias, although most of the samples they use include only the largest listed firms. ${ }^{3}$ The selection of such samples may result in the average characteristics of the sample differing from those of the population (Vella, 2000). Without addressing this selection effect, the association between corporate governance and performance is not inferred correctly, as the impact of corporate governance is confounded with the impact of parameters that determine the selection (Heckman, 1979).

The weak and conflicting results from prior studies may also be explained by not or not properly controlling for endogeneity. An important issue in studying the relation between corporate governance and firm performance is the direction of causation (Bhagat and Black, 2002; Börsch-Supan and Köke, 2002; Drobetz et al., 2003; Klapper and Love, 2004). This direction is not clear ex ante. For instance, as Bhagat and Black (2002, pp. 237) note, "Board composition could affect firm performance, but firm performance can also cause the firm to change its board composition.”

This reverse causality, in which performance affects corporate governance, may lead to biased ordinary least squares (OLS) estimates. The direction of the bias depends on whether performance has a negative or positive reverse effect on corporate governance. Bhagat and

\footnotetext{
${ }^{3}$ Corporate governance data are often only available for the largest companies. For instance, Deminor ratings are available for the FTSE Eurotop 300 companies which are the 300 largest European companies in terms of market capitalisation (Bauer et al., 2003). Crédit Lyonnais Securities Asia (CLSA) scores only 495 companies in 25 countries and selects the companies on the basis of firm size and investor interest (Durnev and Kim, 2005; Klapper and Love, 2004) and the SharkRepellent database comprises solely US companies that are included in the major indices (Larcker et al., 2004).
} 
Black (2002) show that poor performing companies increase the number of independent board members in an effort to improve performance. This indicates that there is a negative reverse causality between performance and corporate governance. As a consequence, the coefficient of corporate governance is underestimated. This is consistent with Black et al. (2005a) finding a downward bias in OLS estimates when regressing board independence on performance.

A common technique to tackle the endogeneity problem is the use of instruments. A number of prior studies have employed this technique (Black et al., 2005a; Drobetz et al., 2003; Durnev and Kim, 2005). However, the instruments used in prior research ${ }^{4}$ are often only weakly correlated with corporate governance, leading to inefficient instrumental variables (IV) estimates. Furthermore, even the smallest correlation between these instruments and the error term may lead to bias in IV estimation that is larger than the bias in OLS estimation (Bound et al., 1995; Nelson and Startz, 1990). ${ }^{5}$ As a consequence, prior studies do not succeed in remedying, and may even worsen, the endogeneity problem.

This overview of prior research shows that some methodological problems remain in studying the link between corporate governance and performance. Furthermore, the issues of selection bias and endogeneity have never been studied together in one model. So the purpose of this study is to control for both selection bias and endogeneity simultaneously in order to find a less biased coefficient of corporate governance.

\section{Model and variables}

\subsection{Model}

To control for sample selection bias and endogeneity, we use the same model as Mroz (1987). Mroz (1987) analyses a set of empirical models of female labour supply and his model that combines both selection bias and endogeneity has been widely referred to in the econometrics literature (Berndt, 1991; Leung and Yu, 1996; Wooldridge, 2002) but, to our knowledge, has never been used before in accounting studies. The model consists of three stages and looks as follows:

\section{(1) Selection equation}

Probit (being in the sample) $=\mathrm{f}($ variables that define the selection process)

\footnotetext{
${ }^{4}$ Instruments used are, among others, legal origin (Durnev and Kim, 2005), market segment indicator variables (Drobetz et al., 2003) and a size indicator variable (Black et al., 2005a).

${ }^{5}$ This may be the reason why some prior studies (e.g. Black et al., 2005a; Durnev and Kim, 2005) find no evidence of an endogeneity problem as the Hausman test may fail to find a significant difference between the OLS and the IV estimator.
} 
Endogenous variable $=\mathrm{f}($ instruments, inverse Mills ratio from stage 1 to control for selection bias, control variables)

\section{(3) Structural equation}

Dependent variable $\quad=\mathrm{f}$ (predicted value of endogenous variable from stage 2 to control for endogeneity, inverse Mills ratio from stage 1 to control for selection bias, control variables)

The purpose of stage $\mathbf{1}$ is to eliminate the problem of selection bias. Controlling for selection bias is usually done by modelling the selection mechanisms explicitly and adjusting the estimation of the parameters in the structural equation for the selection effect (Heckman 1976, 1979). ${ }^{6}$ This is obtained by including a correction term, known as the inverse Mills ratio, in the structural equation. This inverse Mills ratio is calculated from the first stage and reflects how the variables included in this stage are related with the selection of the sample. ${ }^{7}$ This technique boils down to treating the selection bias as a problem of omitted variables.

In our case, and in many corporate governance studies, a specific selection problem occurs, namely that of a truncated sample, as corporate governance data is only available for the largest companies. ${ }^{8}$ Consequently, the sample is not random and the association between corporate governance and performance is not estimated correctly. As the firms in the sample are more homogenous than the total population with regard to their size especially and as size is positively related with performance, the relation between corporate governance and performance is probably underestimated and after including the inverse Mills ratio in the structural equation, the coefficient ( $p$-value) of corporate governance should increase (decrease). ${ }^{9}$

\footnotetext{
${ }^{6}$ Another way to deal with sample selection is through maximum likelihood estimation. This estimation method however relies heavily on distributional assumptions regarding the error terms (Vella, 2000).

7 The inverse Mills ratio is equal to:
}

$$
\varphi\left(\alpha^{\prime} Z\right) / \Phi\left(\alpha^{\prime} Z\right)
$$

The terms $\varphi$ and $\Phi$ are the probability density and cumulative distribution function of the standard normal distribution, respectively. The ratio of $\varphi$ and $\Phi$ evaluated at $\alpha^{\prime} Z$ (with Z comprehending all RHS variables of the first stage) is the inverse Mills ratio and it reflects the truncation of a normal distribution at $\alpha^{\prime} Z$ (Greene, 1997). As the probability of being in the sample increases, the cumulative density function approaches one and the probability density function approaches zero, so the inverse Mills ratio approaches zero. As the probability of being in the sample decreases, the cumulative density function approaches zero at a faster rate than the probability density function approaches zero, so the inverse Mills ratio approaches infinity.

${ }^{8}$ A sample is called truncated if the observations outside a specific range are lost.

${ }^{9}$ Note that the setting in which we employ the inverse Mills ratio to correct for sample selection bias differs from the setting of prior accounting studies that use the Heckman (1979) method (e.g. Bartov et al., 2005; 
So in stage 1, we estimate the probability of being in the selected sample in function of a number of variables that explain the selection using Probit estimation. From this model, we construct an estimate of the inverse Mills ratio, which is then included in stage 2 and 3 of our model.

In stage 2, the problem of endogeneity, more specifically reverse causality, between corporate governance and performance is tackled. Reverse causality leads to corporate governance being correlated with the true (but unobserved) error term of the structural equation, resulting in inconsistent OLS parameter estimates. To solve this problem, usually instrumental variables (IV) estimation is used. In particular, a set of instruments that are assumed to be exogenous is selected and then two-stage least squares (2SLS) is performed. The endogenous variable is first regressed on the instruments and then the estimated value of the endogenous variable is included in the structural equation instead of the endogenous variable itself.

So in stage 2 of our model, we perform the first step of 2SLS estimation. Corporate governance is estimated for the selected sample based on the reduced form equation, which contains the instruments, the inverse Mills ratio from stage 1, and a number of control variables. $^{10}$

In stage 3 the structural equation is then estimated. In this stage, dependent variable of interest, in this case different measures of performance, is regressed on the estimated value of the endogenous variable from stage 2, the inverse Mills ratio from stage 1, and a number of control variables. In doing so, we control for both endogeneity and selection bias at the same time.

\subsection{Variable definition}

We start by discussing the variables included in stage 3 of the model and work our way down through the model, as most variables used in stage 3 also appear in the underlying stages. We collect the financial data from the Worldscope Database of Datastream.

The dependent variables of stage 3 comprise a number of performance measures. We use three market performance measures, namely Tobin's q, market-to-sales ratio (MTS) and

Chaney et al., 2004; Cohen, 2004; Covrig et al., 2005; Harris and Muller, 1999; Hung and Subramanyam, 2004; Leuz and Verrecchia, 2000). While other studies control for self-selection or the treatment effect of observations, we have to control for the loss of observations. This is typical for governance studies and is also a common problem in social research. Yet even in case of a truncated sample, Heckman's two-stage estimator is valid (Puhani, 2000; Vella, 2000; Winship and Mare, 1992; Wooldridge, 2002).

${ }^{10}$ When we use 'stage 1, 2 or 3', we refer to the different stages of our model. When we refer to the two stages of 2SLS, we use the wording 'step 1' and 'step 2', in order to avoid any confusion. 
market-to-book value (MTBV). ${ }^{11}$ We also use two accounting-based measures, namely return-on-assets (ROA) and return-on-equity (ROE) (Bauer et al., 2003; Bhagat and Black, 2002; Klapper and Love, 2004).

Our regressor of interest in stage 3 is the corporate governance of companies. To control for reverse causality in this regression, we use the estimated corporate governance from stage 2 (CGFIRM estimated). We also introduce a number of control variables. First of all, we control for the size of the company (Bhagat and Black, 2002; Durnev and Kim, 2005; Larcker et al., 2004), measured by the natural log of market value of equity (LNMV). Next, we introduce the age of a company (LNAGE) (Black et al., 2005a), our proxy for which is the natural $\log$ of 2003 minus the year from which Datastream has information about the company. ${ }^{12}$ We also include a measure of the growth of the company (Larcker et al., 2004), namely SALESGR. This variable is measured as the average growth in sales over three years (Black et al., 2005a). We introduce measures for the leverage of a company (LEVERAGE) (Black et al., 2005a), the extent of ownership concentration (number of closely held shares ${ }^{13}$ over total shares outstanding, OWNCONC) (Bhagat and Black, 2002; Black et al., 2005a), and the capital intensity ratio (proportion of fixed assets, CAPINT) (Bhagat et al., 2005a; Klapper and Love, 2004). We include an indicator variable to control for companies with a negative net income (LOSS) and one to control for the accounting standards used (ACCSTAND). This latter variable is equal to one if a company uses IFRS or US GAAP. The inverse Mills ratio calculated from stage 1 is also included in this regression to control for sample selection bias. Finally, we control for year and industry effects by incorporating year and industry indicator variables (Bhagat and Black, 2002; Klapper and Love, 2004; Himmelberg et al., 1999).

In stage 2, corporate governance is the dependent variable. We use the corporate governance ratings of Deminor Rating. Deminor Rating is a European rating agency that

\footnotetext{
${ }^{11}$ We calculate Tobin's q as total assets plus market value of equity minus book value of equity scaled by total assets (Bauer et al., 2003; Durnev and Kim, 2005; Klapper and Love, 2004;). Market-to-sales is measured as market value of equity at year end divided by total sales, while market-to-book value is calculated as market value at year end divided by book value of equity (Black et al., 2005a). As a robustness check, we specified market value of equity as shares outstanding multiplied by the average of the highest and lowest share price over the fiscal year. Our results are not significantly influenced.

${ }^{12}$ This is a very crude measure of the age of a company, but no other measures with sufficient observations are available in Datastream.

${ }^{13}$ These include shares held by officers, directors and their immediate family, shares of the company held by another corporation, shares held by pension or benefit plans and shares held by individuals who hold $5 \%$ or more of the outstanding shares.
} 
scores each year the companies belonging to the FTSE Eurotop $300 .^{14}$ The ratings are based on a corporate governance grid comprehending more than 300 criteria. $^{15}$ The maximum score on the index is 40 .

As independent variables in stage 2, we introduce instruments for the corporate governance ratings and a number of control variables. A good instrument has a strong correlation with the endogenous variable, but is not correlated with the error term of the structural equation, i.e. it is exogenous. However, in practise it is extremely difficult to find such an instrument (Maddala, 1977). Therefore, most empirical studies work with 'imperfect' instruments. These imperfect instruments are either exogenous but have a low correlation with the endogenous variable, so-called 'weak instruments', or are not exogenous but have a high correlation with the endogenous variable, so-called 'semi-exogenous' or 'quasiinstrumental' variables. Both types of imperfect instruments have disadvantages and in applying these instruments researchers have to take care that IV estimation indeed leads to less bias than OLS estimation (Bartels, 1999; Larcker et al., 2004). If not, OLS estimation should be used instead of IV estimation.

Earlier corporate governance studies have relied mostly on weak instruments. However, it is widely recognized in the econometrics literature that the use of weak instruments may lead not only to inefficient but also to such inconsistent estimates when they are not completely exogenous that in the majority of the cases OLS estimation should be preferred (Bound et al., 1995; Kennedy, 1985; Nelson and Startz, 1990). Therefore, in this study, we avoid using weak instruments and we define instruments that are strongly correlated with the endogenous variable, but that are maybe not exogenous. We also carefully evaluate their degree of exogeneity and we perform some tests to see whether our results are robust.

As we have panel data, a first possible instrument is company corporate governance ratings lagged one year $\left(\mathrm{CGFIRM}_{\mathrm{t}-1}\right)$. This instrument should be highly correlated with the endogenous variable because it is difficult to reverse corporate governance provisions once they are installed. ${ }^{16}$ Furthermore, this instrument is less endogenous than the current rating as performance in year $\mathrm{t}$ cannot influence corporate governance decisions in year $\mathrm{t}-1$. However,

\footnotetext{
${ }^{14}$ The FTSE Eurotop 300 (now called the FTSEurofirst 300) comprehends the 300 largest capitalized European companies that have sufficient liquidity and free float and that are included in the major indices in Europe (FTSEurofirst, 2005).

${ }^{15}$ In 1998 this grid was tested on a number of companies and since 1999 it is used consistently to score the FTSE Eurotop 300 companies. We only use the ratings starting from 1999 in our dataset. A drawback of these ratings is that they are based on disclosure and not on the actual practices of companies.

${ }^{16}$ By correlation we mean the correlation keeping all other variables constant. This can be measured by means of the partial $\mathrm{R}^{2}$ of a regression of the endogenous variable on the instrument and control variables. The partial $\mathrm{R}^{2}$ of the instrument is then calculated as (Larcker and Rusticus, 2004):

$\left(\mathrm{R}^{2}\right.$ of the full model $-\mathrm{R}^{2}$ of the model without the instrument $) /\left(1-\mathrm{R}^{2}\right.$ of the model without the instrument).
} 
performance in $\mathrm{t}-1$ is related with corporate governance in $\mathrm{t}-1$ and performance in $\mathrm{t}-1$ could be correlated with performance in year t. So the degree of exogeneity of this instrument depends on how current performance is related with past performance.

Secondly, we define a country-level variable as an instrument. According to BörschSupan and Köke (2002), uncontroversial instruments are those that are determined outside the firm but that affect the firm. Prime candidates are macroeconomic variables or government regulation. For instance, Bauer et al. (2003) finds large and statistically significant differences across countries with regard to the average firm-level corporate governance rating. Also Klapper and Love (2004) show that companies' corporate governance practices are related with country-level characteristics. These findings suggest that corporate governance is strongly determined by country-specific factors.

One country factor that could be linked with companies' corporate governance practices is the number of corporate governance recommendations published in a country. Hence, we use a country corporate governance score (CGCOUNTRY) as an instrument for companies' corporate governance practices. For each year, we score countries on their corporate governance recommendations on the basis of an extensive corporate governance index. ${ }^{17}$ This index consists of 48 principles gathered from the OECD Principles of Corporate Governance (1999). We collect data on the corporate governance recommendations from the European Corporate Governance Institute (ECGI, 2005) and from the European Commission (EC, 2002). We then verify whether or not the principles in our index appear in the country recommendations and simply sum up the scores. ${ }^{18}$ The maximum score obtainable on the index is 48 .

This country score is likely correlated with the corporate governance practices of companies as the use the 'comply-or-explain' rule exerts some pressure on companies to comply with the codes. Furthermore, the recommendations can be seen as exogenous or predetermined with regard to the performance of companies. Companies normally do not have any influence on the recommendations decided at country or stock exchange level. However, it could be the case that in countries with many well-performing companies corporate governance recommendations are more extended because these are richer countries. On the other hand, in countries with a lot of weak performing companies investors could pressure government and stock exchange regulators more to establish many corporate

\footnotetext{
${ }^{17}$ We measure the extensiveness of corporate governance recommendations at the beginning of each year. In other words, the score in 2003 is based on the corporate governance codes available in January 2003. This is done to allow companies some time to incorporate the recommendations.

${ }^{18}$ Details of the index can be found in Renders and Gaeremynck (2005).
} 
governance recommendations. So although this instrument is probably largely exogenous, we cannot prove that it is completely exogenous.

Ideally, we would like to combine these two instruments to incorporate both firm-specific and country-level changes in corporate governance over the past years. In section 6.3 we evaluate these instruments and decide on the best set of instruments.

In addition to the instruments and the inverse Mills ratio, we introduce in stage 2 also a number of control variables. These are the same as in stage 3 and include year and industry fixed effects.

Finally, in stage 1, we model the selection of our sample. Our sample consists of the companies included in the FTSE Eurotop 300 that received a corporate governance rating from Deminor. Of course the market value of a company is an important explanatory variable. Besides size, we also include the other control variables used in stage 2 and 3 as explanatory variables, except for the indicator variable for the accounting standards used. Finally, we add some extra explanatory variables, so-called exclusion restrictions, to reduce the collinearity between the inverse Mills ratio and the control variables of stage 2 and $3 .{ }^{19}$ First of all, we include two extra company variables, namely the number of stock exchanges a company is listed on (LISTING) and the percentage of intangible assets (PERCIA). Secondly, we incorporate in this stage also a number of country-level variables, namely the natural log of GDP per capita (GDP) and the ratio of stock market capitalisation over GDP (MARKCAP) (Doidge et al., 2004). Countries with a higher level of financial development and a broader stock market are expected to have better performing companies with larger market values. Hence, the level of development of a country may influence the probability of being in the sample and by including these two country variables we control for differences in the selection process between countries. In this regression we also control for year and industry effects.

Table 1 gives an overview of the variables included in each stage of the model and their definitions.

Insert Table 1 about here

\footnotetext{
${ }^{19}$ As the inverse Mills ratio is calculated on the basis of the variables included in stage 1 and is added as an extra variable in stage 2 and 3, having the same variables in all the stages could lead to a high collinearity between the inverse Mills ratio and the control variables in stage 2 and 3. This can be avoided by including in stage 1 a number of variables that are not included in the other stages of the model (Puhani, 2000; Vella, 2000).
} 


\section{Sample}

We use two different samples to estimate our model. The sample used in stage 2 and 3 is restricted to the companies included in the FTSE Eurotop 300 for which we have corporate governance data. Our sample period runs from 1999 to 2003. Table 2 gives an overview of this restricted sample by country and year. ${ }^{20}$ Companies for which we could not obtain financial information in Datastream are excluded from the sample, as are investment funds and companies with negative book value of equity. The sample consists of 1,199 firm-year observations across 14 countries. Austria has only 5 firm-year observations $(0.4 \%)$ in the sample while the UK has 373 firm-year observations (31.1\%). The large difference between countries in the number of companies in our sample may indicate that country characteristics, such as the level of development and the size of the capital market, influence the selection process.

Insert Table 2 about here

As we investigate in stage 1 the determinants of receiving a corporate governance rating, we collect all listed companies of the 14 EU countries included in our FTSE Eurotop 300 sample from Datastream. ${ }^{21}$ Table 3 gives an overview of this total population of listed companies per country and year. We have a total of 33,667 firm-year observations, after excluding the investment funds and companies with negative book value of equity. Our FTSE Eurotop 300 sample makes up about $3.6 \%$ of the total population and is hence severely truncated.

Insert Table 3 about here

\section{Descriptive statistics}

Table 4 gives an overview of the average company corporate governance rating per country and per year. Portuguese companies have on average the lowest ratings (13.46). The average rating of UK companies (28.17) is more than twice the rating of Portugal. Across all countries and all years, the average rating is 21.95 and the ratings increase over time.

\footnotetext{
${ }^{20}$ Our sample is rather consistent over time as the probability of obtaining a rating in year $\mathrm{t}+1$, given that the company had a rating in year $t$ is about 0.7 .

${ }^{21}$ Deminor Rating has ratings for three other countries not included in our sample, namely Luxembourg, Switzerland and Norway. We excluded Luxembourg because only 1 company received a rating between 1999 and 2002 and only 2 companies in 2003 and we could not find financial data for these companies in Datastream. Switzerland and Norway were excluded because they are not part of the EU.
} 
Insert Table 4 about here

Table 5 gives an overview of the country scores on the corporate governance index per year. Austria has on average the lowest corporate governance recommendations (7) as it only issued a corporate governance code at the end of 2002. The UK has on average the most extensive corporate governance recommendations (37.62). As is the case with the company corporate governance ratings, country scores are also increasing over time.

Insert Table 5 about here

\section{Results}

\subsection{OLS regressions without controls for selection bias and endogeneity}

Before we start with our three-stage model, we first report the results of OLS regressions without controlling for either sample selection bias or endogeneity (see Table 6). ${ }^{22}$ These are our benchmark regressions. ${ }^{23}$ We use the FTSE Eurotop 300 sample to run these regressions. The $\mathrm{R}^{2}$ of the regressions are in line with prior studies, ranging from $20 \%$ for ROA to $9 \%$ for MTS. We find that corporate governance does not seem to have any significant impact on performance. In the regressions with ROA and ROE corporate governance even has a negative coefficient. The results also suggest that size has a positive impact on Q. Younger companies appear to have a higher market performance, apart from MTBV, but a lower accounting performance. Furthermore, sales growth seems positively related with all measures but MTBV. Leverage comes up with a negative coefficient in most regressions, while the capital intensity ratio appears to have a negative impact on the market performance measures. Finally, companies with a net loss have a lower Tobin's q, ROA and ROE. Neither ownership concentration nor the accounting standards used are significant.

Insert Table 6 about here

\footnotetext{
${ }^{22}$ All regressions are run with time and industry fixed effects. The standard errors are heteroskedasticity robust, clustered at the firm level. We report two-tailed p-values. The variance inflation factors (VIFs) are all below 1.85 which suggests that no multicollinearity problems are present in our regressions.

${ }^{23}$ Ideally, we would like to benchmark our three-stage results against prior studies. This is however not possible as none of the prior studies uses panel data and only very few studies adopt a cross-country approach.
} 


\subsection{Stage 1}

In stage 1, the selection process is modelled. The dependent variable indicates whether or not company i received a rating in year t. The regression looks as follows:

$$
\begin{aligned}
& \operatorname{PROBIT}\left(\text { RATING }_{\mathrm{it}}\right)=\alpha+\beta_{1} \mathrm{LNMV}_{\mathrm{it}}+\beta_{2} \mathrm{LNAGE}_{\mathrm{it}}+\beta_{3} \mathrm{SALESGR}_{\mathrm{it}}+\beta_{4} \mathrm{LEVERAGE}_{\mathrm{it}}+ \\
& \beta_{5} \text { OWNCONC }_{\text {it }}+\beta_{6} \text { CAPINT }_{\text {it }}+\beta_{7} \text { LOSS }_{\text {it }}+\beta_{8} \text { LISTING }_{i t}+\beta_{9} \text { PERCIA }_{i t}+ \\
& \beta_{10} \text { GDP }_{\mathrm{it}}+\beta_{11} \text { MARKCAP }_{\mathrm{it}}+\sum \beta_{\mathrm{t}} \text { TIME EFFECTS }_{\mathrm{t}}+\sum \beta_{\mathrm{k}} \text { INDUSTRY } \\
& \text { EFFECTS }_{\mathrm{k}}+\varepsilon_{\text {it }}
\end{aligned}
$$

We use all the listed companies of our 14 countries from Datastream to estimate this regression (see Table 3). Before we discuss the regression results, we first compare the total population of listed companies to the selected sample based on the performance measures and all control variables of the model (see Table 7). Large differences may give a first indication that selection bias is present (Vella, 2000). Table 7 shows that the FTSE Eurotop 300 companies perform on average much better compared to the total population of listed companies. We find that the means of the performance measures are all significantly larger for the companies in the FTSE Eurotop 300. ${ }^{24}$ Table 7 also shows that the FTSE Eurotop 300 companies are on average larger, older, higher leveraged and less concentrated in ownership. They have a lower growth in sales, probably because they are on average older and larger. The FTSE Eurotop 300 companies have also fewer losses, are listed on more stock exchanges and have a higher percentage of intangible assets. However, they do not differ from the total population with regard to their proportion of fixed assets or the accounting standards they use. Finally, they are more likely domiciled in countries with a higher GDP, but not with a higher market capitalisation.

Insert Table 7 about here

Table 8 presents the multivariate results of the first-stage regression. The pseudo $\mathrm{R}^{2}$ of the model is about $70 \%$. Almost all variables are significant (including time and industry indicators), except for CAPINT $(p=0.837)$ and LOSS $(p=0.674)$. Thus the selection seems

\footnotetext{
${ }^{24}$ Based on these univariate results, it seems logical to include in the first stage also measures of the performance of companies as explanatory variables. However, this could lead to inconsistent results in the third stage as we create an endogeneity problem between the dependent variable and the inverse Mills ratio (Maddala, 1983, pp. 118-121; Cohen 2004; Leuz and Verrecchia, 2000).
} 
to rely on more variables than just market value. Larger and older companies with a smaller growth in sales, a higher debt-to-equity ratio and a lower ownership concentration are more likely to belong to the FTSE Eurotop 300 companies. Furthermore, these companies are often listed on more stock exchanges, have a higher percentage of intangible assets and come more frequently from a country with a higher GDP per capita and a larger stock market. These results are largely consistent with the univariate results and the fact that most estimated coefficients of this model are highly significant is again an indication that selection bias could be present (Stolzenberg and Relles, 1997).

Insert Table 8 about here

\subsection{Stage 2}

In the second stage, we estimate a reduced-form regression of the corporate governance ratings on the instruments, the inverse Mills ratio and a number of control variables. The goal of this regression is to get a predicted value for corporate governance that is less influenced by the reverse causality with performance. Before we estimate the regression, we first have to decide which set of instruments is the best set.

According to Bartels (1991) one can choose between instrumental variables based on the asymptotic mean squared error criterion. The instrument or set of instruments for which the asymptotic mean squared error (AMSE) is minimized should be selected. In doing so, the estimation bias is also minimized. The AMSE can be calculated as follows:

$$
\operatorname{AMSE}\left(b^{\mathrm{IV}}\right) \approx\left[\rho^{2} \mathrm{ZU}+1 / \mathrm{n}\right] / \rho^{2} \mathrm{XZ}
$$

where $\rho^{2} \mathrm{ZU}$ is the squared correlation between the instrument(s) $\mathrm{z}$ and the error term of the structural equation $\mathrm{u}$, and $\rho^{2} \mathrm{xz}$ is the squared correlation between the instrument(s) $\mathrm{z}$ and the endogenous variable $\mathrm{x}$. So the asymptotic mean squared error is proportional to the endogeneity of the instrument(s) and inversely proportional to the efficiency of the instrument(s). In other words, the higher the correlation with the endogenous variable, the higher the correlation with the error term can be without affecting the bias. The only drawback of this criterion is that the squared correlation between the instrument(s) and the error term is unobservable and hence judgement has to be used.

We have three different sets of instruments, namely corporate governance ratings lagged one year $\left(\right.$ CGFIRM $\left._{\mathrm{t}-1}\right)$, country scores on the corporate governance index (CGCOUNTRY), 
and a combination of the two previous instruments $\left(\right.$ CGFIRM $_{\mathrm{t}-1} \& \mathrm{CGCOUNTRY}$. However, we can already eliminate the first set $\left(\mathrm{CGFIRM}_{\mathrm{t}-1}\right)$. The reason is that compared to the set of the combined instruments $\left(\mathrm{CGFIRM}_{\mathrm{t}-1}\right.$ \& CGCOUNTRY), the AMSE of the lagged ratings will always be higher. This is because by adding the rather exogenous country-level instrument, $\rho^{2} \mathrm{XZ}$ increases and $\rho^{2} \mathrm{ZU}$ decreases, leading to a lower AMSE.

For the two remaining sets, we calculate $\rho^{2} \mathrm{xz}$ as the partial correlation between the endogenous variable and the instruments based on the second-stage regression. This partial correlation amounts to $79 \%$ for the combined set and is about $17 \%$ for the country level instrument. So we have to choose between using an instrument (CGCOUNTRY) with a rather low correlation with the endogenous variable but that is also relatively exogenous and a set of instruments (CGFIRM t-1 $_{\text {\& }}$ CGCOUNTRY) that has a high correlation with the endogenous variable, but that could have a relatively high correlation with the error term. We decide on using the set of combined instruments in our regressions for two reasons. First, the relative endogeneity of the combined set depends mainly on the endogeneity of the lagged ratings, which can be proxied for by the correlation between current and past performance. We calculate this correlation for each performance measure and we find that it does not exceed $29 \%$. ${ }^{25}$ So relative to the correlation with the endogenous variable, the combined set of instruments has a low degree of endogeneity. Secondly, as mentioned previously, we cannot be sure that the use of CGCOUNTRY as a sole instrument leads to a lower bias than OLS, as it has a rather low correlation with the endogenous variable and is probably not completely exogenous. As a robustness check, we run the regressions with the country corporate governance scores as a sole instrument and we find that our results still hold. However, the pvalues increase when we use this instrument, indicating that it has a lower efficiency than our combined set.

So the second-stage regression with the combined set of instruments looks as follows:

$$
\begin{aligned}
\text { CGFIRM }_{\text {it }}=\alpha+\beta_{1} \text { CGFIRM }_{\mathrm{it}-1}+\beta_{2} \text { CGCOUNTRY }_{\mathrm{it}}+\beta_{3} \text { LNMV }_{\mathrm{it}}+\beta_{4} \text { LNAGE }_{\mathrm{it}} \\
+\beta_{5} \text { SALESGR }_{\mathrm{it}}+\beta_{6} \text { LEVERAGE }_{\mathrm{it}}+\beta_{7} \text { OWNCONC }_{\mathrm{it}}+\beta_{8} \text { CAPINT }_{\mathrm{it}}+\beta_{9} \text { LOSS }_{\mathrm{it}} \\
+\beta_{10} \text { ACCSTAND }_{\mathrm{it}}+\beta_{11} \text { MILLS }_{\mathrm{it}}+\sum \beta_{\mathrm{t}} \text { TIME EFFECTS }_{\mathrm{t}}+\sum \beta_{\mathrm{k}} \text { INDUSTRY } \\
\text { EFFECTS }_{\mathrm{k}}+\varepsilon_{\mathrm{it}}
\end{aligned}
$$

Table 9 gives the results of stage 2 . The $\mathrm{R}^{2}$ of the regression is $83 \%$. The results of this regression indicate that our instruments are appropriate. First of all, both lagged corporate

\footnotetext{
${ }^{25}$ The correlation is $29 \%$ for Tobin's q and MTS, $26 \%$ for MTBV, $17 \%$ for ROA and $7 \%$ for ROE.
} 
governance practices $(p<0.001)$ and corporate governance recommendations $(p=0.001)$ are significantly correlated with current ratings. Secondly, the partial $\mathrm{R}^{2}$ of the instruments is high, about $79 \%$. A final way to test whether the instruments are appropriate is to compute the F-statistic that tests the joint significance of the regression coefficients of the instruments. This statistic is highly significant $(\mathrm{p}<0.001)$, so the null hypothesis that the coefficients on the instruments are equal to zero can be rejected (Drobetz et al., 2003; Wooldridge, 2002).

Insert Table 9 about here

\subsection{Stage 3}

In stage 3, we regress performance on the estimated values of the corporate governance ratings from stage 2, the inverse Mills ratio from stage 1 and a number of control variables. The model looks as follows:

Performance $_{i t}=\alpha+\beta_{1}$ CGFIRM estimated $_{i t}+\beta_{2}$ LNMV $_{i \mathrm{t}}+\beta_{3}$ LNAGE $_{i t}+\beta_{4}$ SALESGR $_{i t}$ $+\beta_{5}$ LEVERAGE $_{i t}+\beta_{6}$ OWNCONC $_{i t}+\beta_{7}$ CAPINT $_{i t}+\beta_{8}$ LOSS $_{i t}+\beta_{9}$ ACCSTAND $_{i t}$ $+\beta_{10}$ MILLS $_{\mathrm{it}}+\sum \beta_{\mathrm{t}}$ TIME EFFECTS $_{\mathrm{t}}+\sum \beta_{\mathrm{k}}$ INDUSTRY EFFECTS $_{\mathrm{k}}+\varepsilon_{\mathrm{it}}$

The results are presented in Table 10 . The $\mathrm{R}^{2}$ of the regressions varies between $21 \%$ for ROA and 9\% for MTS after controlling for selection bias and endogeneity. The Hausman test confirms there is an endogeneity problem for all measures. The results also show that sample selection bias is present, as the inverse Mills ratio is significant in each regression. But most importantly, we find that corporate governance has a significantly positive impact on every performance measure.

Our results with regard to firm value are economically significant. We find that a worstto-best increase in the corporate governance ratings leads to an increase of about $86 \%$ in Tobin's q and about $80 \%$ in the market-to-sales ratio. Prior studies find that a worst-to-best increase in corporate governance causes an increase in Tobin's q of $47 \%$ in developed countries (Gompers et al., 2003) and between 55 and 89\% in emerging countries (Black et al., 2005a; Klapper and Love, 2002). Our coefficient of corporate governance in the regressions with Tobin's q is also at least $40 \%$ larger than the coefficient found in prior studies (Black et al., 2005a; Klapper and Love, 2002; Gompers et al., 2003). For the market-to-sales ratio, it is even 3 times as large (Black et al., 2005a), while the coefficient in the regressions with MTBV is of about the same size as the one found in prior research (Black et al., 2005a). 
The coefficients we find in the regressions with the profitability measures are rather high compared to prior research. For instance, Black et al. (2005a) find for both ROA and ROE a coefficient that is negative and close to zero ( -0.0002 and -0.0045 respectively). Also Gompers et al. (2003) find a coefficient on ROE that is very close to zero $(0.0003) .{ }^{26}$ In contrast, Klapper and Love (2002) find a coefficient on ROA that is 13 times higher than our coefficient (0.13).

Insert Table 10 about here

When we compare the coefficients and p-values of corporate governance with those of the OLS regressions without controls (see Table 6), we find that after controlling for endogeneity and selection bias, the coefficients increase and the p-values decrease. Moreover, the coefficient even changes from negative to positive for ROA and ROE. This confirms our proposition that the insignificance of corporate governance in prior studies is attributable to failure to control for sample selection bias and endogeneity which leads to an underestimation of the coefficient of corporate governance.

When we compare our findings with those of prior research in Europe, we find that our results contrast with the results of Bauer et al. (2003). They find a small negative relation between corporate governance and accounting-based performance measures and only a weak positive relation with firm value. This negative relation between corporate governance and accounting-based measures clearly arises from the failure to control for selection bias and endogeneity, as we find a positive relation after controlling for both problems. Our results confirm the results of Drobetz et al. (2003) and generalise their findings to other EU countries besides Germany.

\section{Step by step approach}

Instead of going from the OLS estimation results to the results of the three-stage model, Table 11 shows what happens to the coefficient and p-value of corporate governance when we would control for either sample selection bias or endogeneity. For simplicity we report only the statistics for the coefficient on the corporate governance ratings. The first column presents the results from the OLS regressions without controls while the last column gives the p-values and coefficients of corporate governance from our three-stage model. In the OLS regressions,

\footnotetext{
${ }^{26}$ Gompers et al. (2003) however use industry adjusted performance measures.
} 
none of the coefficients is significant, with even a negative coefficient in the regressions with ROA and ROE. The coefficients become significantly positive in our three-stage model.

Insert Table 11 about here

The second column shows the results after controlling for sample selection bias using the Heckman (1979) procedure. After controlling for selection bias, the coefficient of corporate governance increases compared to OLS. The coefficient even becomes significant for Tobin's $\mathrm{q}$ and MTS and is slightly above significance level for MTBV. For the accounting measures, the sign of the coefficient changes from negative to positive, but does not become significant.

The third column of the table gives the coefficients and p-values of corporate governance after controlling for endogeneity through 2SLS. The instruments used are the same as in our three-stage model. We find that all coefficients increase and become significant for the market measures. Again the coefficients in the regressions of ROA and ROE change signs compared to the results under OLS.

The increase in the coefficients after controlling for endogeneity indicates that the causality running from performance to corporate governance has a negative sign, suggesting that when performance worsens, companies improve their corporate governance. This result is consistent with the findings of Drobetz et al. (2003), Black et al. (2005a) and Bhagat and Black (2002).

If we compare the results of each of these separate steps with the results of our three-stage model, we can conclude that controlling for both sample selection bias and endogeneity at the same time leads to the highest increase in the coefficient of corporate governance. The coefficient in the regressions with ROA and ROE even becomes significant in our three-stage models, whereas it is insignificant after controlling for either sample selection bias or endogeneity. Furthermore, both problems contribute equally to the bias in the coefficient of corporate governance, as the coefficients are of about the same size after controlling for either selection bias or endogeneity. Finally, compared to the 2SLS estimation, that has been used by some prior studies, the coefficient of corporate governance in the three-stage model increases with at least $50 \%$. So we can conclude that both sample selection bias and endogeneity have an impact on the coefficient of corporate governance and its significance. As a consequence, it is necessary to control for both these problems at the same time, as this leads to the highest coefficient of corporate governance. 


\section{Sensitivity}

We performed a number of sensitivity checks with regard to the instruments used. First of all, we estimate the regressions with corporate governance ratings lagged two periods and the country scores as instruments. The reason we did this is that ratings lagged two periods may be more exogenous than ratings lagged only one period, as performance from two periods ago likely exhibits a lower correlation with current performance. Our results do not change. Secondly, we excluded lagged ratings and only used the country scores as an instrument and we find that our results still hold. However, the p-value increase when we use only the country scores as an instrument, indicating that the efficiency is lower than the efficiency of the set consisting of both ratings lagged one period and the country scores.

We also performed some sensitivity tests with regard to our sample composition. First, we exclude the UK from our regressions, as UK companies make up about $32 \%$ of both our samples. We find that our results are not significantly influenced. We also run the regressions with country dummies. In doing so, the country variables in stage 1 are excluded from the regression. Again we find that our results are robust. Finally, we exclude all countries that have fewer than 5 observations in every year. Hence, we drop Austria, Denmark, Finland, Greece, Ireland and Portugal and perform the regressions with the other 9 countries. Our results are not significantly influenced.

\section{Conclusion}

The purpose of this paper is to investigate the impact of endogeneity and sample selection bias on the relation between firm performance and corporate governance. Corporate governance studies are plagued with econometric problems of which selection bias and endogeneity are among the most important ones. We tried to control for both these problems simultaneously using panel data over 5 years. We use a sample selection model to incorporate the determinants of being in the selected sample and employ instruments to control for endogeneity.

We find that sample selection bias is present for all measures of performance. The results show further that endogeneity problems arise for both market and accounting performance measures. This indicates that management evaluates performance and decides to improve corporate governance practices when performance is weak. This strategy seems to work, as we find a positive and significant coefficient on corporate governance after controlling for selection bias and endogeneity. Finally, we find that both problems are equally important for 
reducing the bias in the coefficient and that controlling for both problems at the same time reduces the bias considerably.

Overall, the results suggest that controlling for sample selection bias and endogeneity is important in order to infer the true relation between corporate governance and performance. In contrast to prior studies that do not control for sample selection bias and endogeneity, we do find that for European companies corporate governance has a highly significant impact on both firm value and profitability. We therefore recommend that future studies on corporate governance and performance take into account these econometric problems in order to infer the true relation between corporate governance and performance.

This study has a number of implications. First of all, it shows that corporate governance should be seen by companies as a chance to improve their performance, especially in countries where the adoption of corporate governance practices is mainly voluntary. Furthermore, in countries where corporate governance is mandatory, this study shows that there are not only costs associated with the adoption of corporate governance mechanisms but also benefits, such as a higher market value.

Secondly, a suggestion for future research would be to use the model outlined in this study and apply it to the US setting. Until now, governance studies in the US only found very weak evidence of a relation between governance and performance. However, it is not clear whether these results are due to not properly controlling for sample selection bias and endogeneity or to a relation between governance and performance being significantly different from the one in Europe and emerging countries. For instance, it is often argued that the minimum level of corporate governance in the US is very high and that there is little cross-company variation. However, this will be not clear unless US studies take endogeneity and sample selection bias into account. It could also be interesting to use the model for studies in emerging countries. Although earlier studies in emerging countries find significant results with regard to firm value, the estimated coefficient of corporate governance may still be biased and the true coefficient could be higher than the value currently estimated.

There are also a number of limitations associated with this study. First, this study uses European data. As the European setting is different from the US and emerging countries, the results of this study are difficult to generalise. Secondly, we did not take into account the interplay between corporate governance and other governance mechanisms such as the ownership or debt structure of a company. Recent research (e.g. Firth et al., 2004) suggests that these mechanisms are interrelated and that firms choose the optimal structure. However, we partially controlled for this interplay by including a number of control variables that are 
related with the ownership structure and amount of debt. Finally, we only studied the contemporaneous relation between corporate governance and performance. However, it is also possible that corporate governance has a long-term effect on performance. Future studies could look into this issue more closely. 


\section{References}

Angrist J. and Krueger A. (2001). Instrumental Variables and the Search for Identification: From Supply and Demand to Natural Experiments, Journal of Economic Perspectives, $15(4), 69-85$.

Arellano M. and Bond S. (1991). Some Tests of Specification for Panel Data: Monte Carlo Evidence and an Application to Employment Equations, Review of Economic Studies, 58(194), 277-297.

Bartels L. (1991). Instrumental and "Quasi-Instrumental" Variables, American Journal of Political Science, 35(3), 777-800.

Bartov E., Goldberg S., and Kim M. (2005). Comparative Value Relevance Among German, U.S., and International Accounting Standards: A German Stock Market Perspective, Journal of Accounting, Auditing and Finance, 20(2), pp. 95-119.

Bauer R., Günster N., and Otten R. (2003). Empirical Evidence on Corporate Governance in Europe: The Effect on Stock Returns, Firm Value and Performance, Forthcoming in Journal of Asset Management.

Berndt E. (1991). The Practice of Econometrics: Classic and Contemporary, AddisonWesley, New York, NY.

Bhagat S. and Black B. (2002). The Non-Correlation Between Board Independence and Long-Term Firm Performance, The Journal of Corporation Law, 27(2), 231-272.

Bhagat S. and Jefferis R. (2002). The Econometrics of Corporate Governance Studies, MIT Press, Cambridge, pp. 114.

Black B. (2001). The Corporate Governance Behavior and Market Value of Russian Firms, Emerging Markets Review, 2(2), 89-108.

Black B., Jang H., and Kim W. (2005a). Does Corporate Governance Predict Firm's Market Values? Evidence from Korea, Forthcoming in Journal of Law, Economics and Organisation.

Black B., Jang H., and Kim W. (2005b). Predicting Firms' Corporate Governance Choices: Evidence from Korea, Law and Ecomics Working Paper No. 39, University of Texas Law School, pp. 33.

Börsch-Supan A. and Köke J. (2002). An Applied Econometricians' View of Empirical Corporate Governance Studies, German Economic Review, 3(3), 295-326.

Bound J, Jaeger D., and Baker R. (1995). Problems with Instrumental Variables Estimation when the Correlation Between the Instruments and the Endogenous Explanatory Variable is Weak, Journal of the American Statistical Association, 90(430), 443-450. 
Chaney P., Jeter D., Shivakumar L. (2004). Self-Selection of Auditors and Audit Pricing in Private Firms, The Accounting Review, 79(1), pp. 51-72.

Covrig V., DeFond M., and Hung M; (2005). Home Bias, Foreign Mutual Fund Holding, and the Voluntary Adoption of International Accounting Standards, Working Paper, University of Southern California.

Cuddleback G., Wilson E., Orme J., and Combs-Orme T. (2004). Detecting and Statistically Correcting Sample Selection Bias, Journal of Social Service Research, 30(3), 19-33.

Drobetz W., Schillhofer A., and Zimmermann H. (2003). Corporate Governance and Expected Stock Returns: Evidence from Germany, ECGI Finance Working paper No. 11/2003, pp. 46.

Doidge C., Karolyi G., and Stulz R. (2004). Why Do Countries Matter so Much for Corporate Governance?, ECGI Finance Working Paper $N^{\circ} .50 / 2004$, pp. 52.

Durnev A. and Kim E. (2005). To Steal or Not to Steal: Firm Attributes, Legal Environment, and Valuation, Journal of Finance, 60(3), 1461-1493.

European Commission (2002). Comparative Study of Corporate Governance Codes Relevant to the European Union and its Member States, www.europa.eu.int.

European Corporate Governance Institute (2005). 'Corporate Governance Codes, Principles, and Recommendations' (online), www.ecgi.org.

Firth M., Fung P., and Rui O. (2002). Simultaneous Relationships among Ownership, Corporate Governance, and Financial Performance, Working Paper, Hong Kong Polytechnic University, pp. 40.

Francis J. and Wilson E. (1988). Auditor Changes: A Joint Test of Theories Relating to Agency Costs and Auditor Differentiation, The Accounting Review, 63(4), pp. 663-682.

Gompers P., Ishii J., and Metrick A. (2001). Corporate Governance and Equity Prices, Quarterly Journal of Economics, 116(1), 107-155.

Hausman J. (1978). Specification Tests in Econometrics, Econometrica, 46(6), 1251-1271.

Harris M. and Muller K. (1999). The Market Valuation of IAS versus US GAAP Accounting Measures Using Form 20-F reconciliations, Journal of Accounting and Economics, 26(13), pp. 285-312.

Heckman J. (1976). The Common Structure of Statistical Models of Truncation, Sample Selection and Limited Dependent Variables and a Simple Estimator for Such Models, The Annals of Economic and Social Measurement, 5, 475-492.

Heckman J. (1979). Sample Selection Bias as a Specification Error, Econometrica, 47(1), 153-162. 
Himmelberg C., Hubbard G., and Palia D. (1999). Understanding the Determinants of Managerial Ownership and the Link between Ownership and Performance, Journal of Financial Economics, 53(3), 353-384.

Hung M., and Subramanyam K. (2004). Financial Statements Effects of Adopting International Accounting Standards: The Case of Germany, Working Paper, University of Southern California.

Kennedy P. (1985). A Guide to Econometrics, 2d ed., Cambridge, MIT Press.

Klapper L. and Love I. (2004). Corporate Governance, Investor Protection, and Performance in Emerging Markets, Forthcoming in Journal of Finance.

Landsman W., Lang M., and Yeh S. (2005). Governance and the Split of Options between Executive and Non-executive Employees, Working Paper, University of North Carolina, pp. 34.

Larcker D., Richardson S., and Tuna I. (2004). How Important is Corporate Governance?, Working Paper, Wharton School, University of Pennsylvania, pp. 84.

Larcker D. and Rusticus T. (2004). On the Use of Instrumental Variables in Accounting Research, Working Paper, Wharton School, University of Pennsylvania, pp. 48.

Leung S. and Yu S. (1996). On the Choice Between Sample Selection and Two-part Models, Journal of Econometrics, 72(1-2), 197-229.

Leuz C., and Verrecchia T., (2000). The Economic Consequences of Increased Disclosure, Journal of Accounting Research, 38, pp. 91-124.

Linden P. and Matolcsy Z. (2004). Corporate Governance Scoring Systems: What Do They Tell Us?, Australian Accounting Review, 14(1), pp. 9-16.

Matolcsy Z., Stokes D. and Wright A. (2004). Do Independent Directors Add Value?, Australian Accounting Review, 14(1), pp. 33-40.

Mroz T. (1987). The Sensitivity of an Empirical Model of Married Women's Hours of Work to Economic and Statistical Assumptions, Econometrica, 55(4), 765-799.

Nelson C. and Startz R. (1990). The Distribution of the Instrumental Variables Estimator and its T-ratio when the Instrument is a Poor one, Journal of Business, 63(1), S125-S140.

Nikolaev V. and van Lent L. (2005). The Endogeneity Bias in the Relation between Cost-ofDebt Capital and Corporate Disclosure Policy, Working Paper, Tilburg University, pp. 53. Organisation for Economic Co-operation and Development (OECD). (1999). OECD Principles of Corporate Governance. Doc. No. SG/CG(99)5.

Petersen M. (2005). Estimating Standard Errors in Finance Panel Data Sets: Comparing Approaches. Working Paper, Kellogg School of Management, Northwestern University. 
Puhani P. (2000). The Heckman Correction for Sample Selection and its Critique, Journal of Economic Surveys, 14(1), 53-68.

Renders A. and Gaeremynck A. (2005). The Impact of Legal and Voluntary Investor Protection on the Early Adoption of IFRS, Working Paper, KULeuven, pp. 37.

Rogers W. (1993). Regression Standard Errors in Clustered Samples. Stata Technical Bulletin, 13, 19-23.

Semykina A. and Wooldridge J. (2005). Estimating Panel Data Models in the Presence of Endogeneity and Selection: Theory and Application, Working Paper, Michigan State University, pp. 35.

Short H. (1994). Ownership, Control, Financial Structure and the Performance of Firms, Journal of Economic Surveys, 8(3), 203-249.

Staiger D. and Stock J. (1997). Instrumental Variables Regression with Weak Instruments, Econometrica, 65(3), 557-586.

Stolzenberg R. and Relles D. (1997). Tools for Intuition about Sample Selection Bias and its Correction, American Sociological Review, 62(3), 494-507.

Vella F. (2000). Estimating Models with Sample Selection Bias: A Survey, Journal of Human Resources, 33(1), 127-169.

Williams R. (2000). A Note on Robust Variance Estimation for Cluster-correlated Data. Biometrics, 56(2), 645-646.

Winship C. and Mare R. (1992). Models for Sample Selection Bias, Annual Review of Sociology, 18(1), pp. 327-350.

Wooldridge J. (2002). Econometric Analysis of Cross Section and Panel Data, MIT Press, Cambridge, London. 
Table 1: Variable definitions

\begin{tabular}{|c|c|c|c|c|}
\hline Dependent variables & Definition & Stage 1 & Stage 2 & Stage 3 \\
\hline Q & $\begin{array}{l}=(\text { total assets }+ \text { market value equity } \\
\text { - book value equity }) / \text { total assets }\end{array}$ & & & $\mathrm{X}$ \\
\hline MTS & $=$ market value equity/total sales & & & $\mathrm{X}$ \\
\hline MTBV & $=$ market value equity/book value equity & & & $\mathrm{X}$ \\
\hline ROA & $=($ net income + interest expenses $) /$ total assets & & & $\mathrm{X}$ \\
\hline ROE & $=$ net income/book value equity & & & $\mathrm{X}$ \\
\hline CGFIRM & $=$ corporate governance rating from Deminor Rating & & $\mathrm{X}$ & \\
\hline RATING & $=1$ if company has rating, 0 otherwise & $\mathrm{X}$ & & \\
\hline \multicolumn{5}{|c|}{ Independent variables } \\
\hline CGFIRM estimated & $=$ estimated corporate governance rating from stage 2 & & & $\mathrm{X}$ \\
\hline CGFIRMt-1 & $=$ corporate governance rating lagged 1 period & & $\mathrm{X}$ & \\
\hline CGCOUNTRY & $=$ country corporate governance score & & $\mathrm{X}$ & \\
\hline LNMV & $=\ln ($ market value of equity at year end $)$ & $\mathrm{X}$ & $\mathrm{X}$ & $\mathrm{X}$ \\
\hline LNAGE & $=\ln (2003$-year of incorporation in Datastream $)$ & $\mathrm{X}$ & $\mathrm{X}$ & $\mathrm{X}$ \\
\hline SALESGR & $=$ average growth in total sales over 3 years & $\mathrm{X}$ & $\mathrm{X}$ & $\mathrm{X}$ \\
\hline LEVERAGE & $=$ total debt/book value equity & $\mathrm{X}$ & $\mathrm{X}$ & $X$ \\
\hline OWNCONC & $=$ closely held shares/total shares outstanding ${ }^{\mathrm{a}}$ & $\mathrm{X}$ & $\mathrm{X}$ & $\mathrm{X}$ \\
\hline CAPINT & $=$ fixed assets/total assets & $\mathrm{X}$ & $\mathrm{X}$ & $\mathrm{X}$ \\
\hline LOSS & $=1$ if company has negative net income, 0 otherwise & $\mathrm{X}$ & $\mathrm{X}$ & $\mathrm{X}$ \\
\hline ACCSTAND & $=1$ if company uses IFRS or US GAAP, 0 otherwise & & $\mathrm{X}$ & $\mathrm{X}$ \\
\hline LISTING & $=$ number of listings on stock exchange & $\mathrm{X}$ & & \\
\hline PERCIA & $=$ intangible assets/total assets & $\mathrm{X}$ & & \\
\hline GDP & $=\ln ($ GDP per capita $)$ & $\mathrm{X}$ & & \\
\hline MARKCAP & $=$ total market capitalisation/GDP & $\mathrm{X}$ & & \\
\hline MILLS & $=$ inverse Mills ratio from stage 1 & & $\mathrm{X}$ & $\mathrm{X}$ \\
\hline TIME EFFECTS & $=$ year indicator variables & $\mathrm{X}$ & $\mathrm{X}$ & $\mathrm{X}$ \\
\hline $\begin{array}{l}\text { INDUSTRY } \\
\text { EFFECTS } \\
\end{array}$ & $\begin{array}{l}\text { = industry indicator variables based on two-digit SIC } \\
\text { codes }\end{array}$ & $\mathrm{X}$ & $\mathrm{X}$ & $\mathrm{X}$ \\
\hline
\end{tabular}

\footnotetext{
${ }^{a}$ Closely held shares include shares held by officers, directors and their immediate family, shares of the company held by another corporation, shares held by pension or benefit plans and shares held by individuals who hold $5 \%$ or more of the outstanding shares.
} 
Table 2: Sample of FTSE Eurotop 300 companies $^{\text {a }}$

\begin{tabular}{lrrrrrrr}
\hline & $\mathbf{1 9 9 9}$ & $\mathbf{2 0 0 0}$ & $\mathbf{2 0 0 1}$ & $\mathbf{2 0 0 2}$ & $\mathbf{2 0 0 3}$ & Total & $\mathbf{\%}^{\mathbf{b}}$ \\
\hline Austria & 0 & 0 & 1 & 2 & 2 & $\mathbf{5}$ & 0.4 \\
\hline Belgium & 7 & 9 & 10 & 9 & 9 & $\mathbf{4 4}$ & 3.7 \\
\hline Denmark & 2 & 4 & 7 & 4 & 4 & $\mathbf{2 1}$ & 1.8 \\
\hline Finland & 4 & 5 & 6 & 5 & 5 & $\mathbf{2 5}$ & 2.1 \\
\hline France & 42 & 39 & 37 & 38 & 41 & $\mathbf{1 9 7}$ & 16.4 \\
\hline Germany & 24 & 26 & 32 & 30 & 32 & $\mathbf{1 4 4}$ & 12.0 \\
\hline Greece & 3 & 0 & 3 & 4 & 6 & $\mathbf{1 6}$ & 1.3 \\
\hline Ireland & 4 & 3 & 5 & 5 & 6 & $\mathbf{2 3}$ & 1.9 \\
\hline Italy & 22 & 20 & 22 & 21 & 24 & $\mathbf{1 0 9}$ & 9.1 \\
\hline Netherlands & 20 & 18 & 19 & 17 & 18 & $\mathbf{9 2}$ & 7.7 \\
\hline Portugal & 3 & 0 & 2 & 4 & 4 & $\mathbf{1 3}$ & 1.1 \\
\hline Spain & 9 & 9 & 10 & 13 & 16 & $\mathbf{5 7}$ & 4.8 \\
\hline Sweden & 13 & 17 & 17 & 18 & 15 & $\mathbf{8 0}$ & 6.7 \\
\hline UK & 65 & 74 & 79 & 78 & 77 & $\mathbf{3 7 3}$ & 31.1 \\
\hline Total & $\mathbf{2 1 8}$ & $\mathbf{2 2 4}$ & $\mathbf{2 5 0}$ & $\mathbf{2 4 8}$ & $\mathbf{2 5 9}$ & $\mathbf{1 , 1 9 9}$ & $\mathbf{1 0 0}$ \\
\hline
\end{tabular}

a The sample includes all companies from the FTSE Eurotop 300 companies for which we have corporate governance ratings. We exclude investment funds, companies with missing data and companies with negative book value of equity. We use this sample to estimate stage 2 and 3 of our model.

${ }^{\mathrm{b}}$ Percentage of the total sample.

Table 3: Total population of listed companies ${ }^{\mathrm{a}}$

\begin{tabular}{lrrrrrrr}
\hline & $\mathbf{1 9 9 9}$ & $\mathbf{2 0 0 0}$ & $\mathbf{2 0 0 1}$ & $\mathbf{2 0 0 2}$ & $\mathbf{2 0 0 3}$ & \multicolumn{1}{c}{ Total } & $\mathbf{\%}^{\mathbf{b}}$ \\
\hline Austria & 123 & 122 & 134 & 129 & 135 & $\mathbf{6 4 3}$ & 1.9 \\
\hline Belgium & 135 & 130 & 130 & 133 & 131 & $\mathbf{6 5 9}$ & 2.0 \\
\hline Denmark & 217 & 223 & 226 & 226 & 223 & $\mathbf{1 , 1 1 5}$ & 3.3 \\
\hline Finland & 172 & 172 & 173 & 173 & 175 & $\mathbf{8 6 5}$ & 2.6 \\
\hline France & 1,039 & 1,025 & 1,038 & 1,015 & 1,021 & $\mathbf{5 , 1 3 8}$ & 15.3 \\
\hline Germany & 1,054 & 1,061 & 1,034 & 1,028 & 1,022 & $\mathbf{5 , 1 9 9}$ & 15.4 \\
\hline Greece & 395 & 397 & 395 & 395 & 394 & $\mathbf{1 , 9 7 6}$ & 5.9 \\
\hline Ireland & 77 & 77 & 75 & 75 & 76 & $\mathbf{3 8 0}$ & 1.1 \\
\hline Italy & 365 & 371 & 364 & 361 & 361 & $\mathbf{1 , 8 2 2}$ & 5.4 \\
\hline Netherlands & 227 & 234 & 225 & 223 & 221 & $\mathbf{1 , 1 3 0}$ & 3.4 \\
\hline Portugal & 113 & 111 & 110 & 112 & 110 & $\mathbf{5 5 6}$ & 1.7 \\
\hline Spain & 151 & 150 & 148 & 148 & 149 & $\mathbf{7 4 6}$ & 2.2 \\
\hline Sweden & 449 & 450 & 445 & 457 & 440 & $\mathbf{2 , 2 4 1}$ & 6.7 \\
\hline UK & 2,236 & 2,284 & 2,264 & 2,228 & 2,185 & $\mathbf{1 1 , 1 9 7}$ & 33.3 \\
\hline Total & $\mathbf{6 , 7 5 3}$ & $\mathbf{6 , 8 0 7}$ & $\mathbf{6 , 7 6 1}$ & $\mathbf{6 , 7 0 3}$ & $\mathbf{6 , 6 4 3}$ & $\mathbf{3 3 , 6 6 7}$ & $\mathbf{1 0 0}$ \\
\hline
\end{tabular}

${ }^{a}$ The sample includes all listed companies with financial data in Datastream of the 14 countries included in the FTSE Eurotop 300 sample. We exclude investment funds, companies with missing data and companies with negative book value of equity. We use this sample to estimate stage 1 of our model.

${ }^{\mathrm{b}}$ Percentage of total sample. 
Table 4: Average company corporate governance rating per country and per year

\begin{tabular}{lcccccr}
\hline & $\mathbf{1 9 9 9}$ & $\mathbf{2 0 0 0}$ & $\mathbf{2 0 0 1}$ & $\mathbf{2 0 0 2}$ & $\mathbf{2 0 0 3}$ & Average \\
\hline Austria & - & - & 16.19 & 17.69 & 19.12 & $\mathbf{1 7 . 9 6}$ \\
\hline Belgium & 15.16 & 15.59 & 17.08 & 18.11 & 18.38 & $\mathbf{1 6 . 9 5}$ \\
\hline Denmark & 10.41 & 15.36 & 14.60 & 15.76 & 17.58 & $\mathbf{1 5 . 1 3}$ \\
\hline Finland & 21.94 & 21.44 & 20.15 & 22.23 & 24.41 & $\mathbf{2 1 . 9 6}$ \\
\hline France & 17.68 & 21.05 & 21.31 & 22.46 & 22.44 & $\mathbf{2 0 . 9 4}$ \\
\hline Germany & 18.07 & 19.92 & 18.19 & 18.16 & 20.32 & $\mathbf{1 8 . 9 5}$ \\
\hline Greece & 16.42 & - & 13.30 & 14.65 & 16.52 & $\mathbf{1 5 . 4 3}$ \\
\hline Ireland & 29.40 & 27.74 & 28.71 & 29.10 & 29.87 & $\mathbf{2 9 . 0 9}$ \\
\hline Italy & 17.08 & 18.82 & 18.54 & 17.86 & 18.88 & $\mathbf{1 8 . 2 4}$ \\
\hline Netherlands & 13.05 & 15.42 & 16.10 & 19.09 & 23.44 & $\mathbf{1 7 . 2 9}$ \\
\hline Portugal & 8.80 & - & 11.41 & 13.74 & 17.69 & $\mathbf{1 3 . 4 6}$ \\
\hline Spain & 13.95 & 13.82 & 15.89 & 17.60 & 20.72 & $\mathbf{1 7 . 0 0}$ \\
\hline Sweden & 19.04 & 18.34 & 19.22 & 21.54 & 22.44 & $\mathbf{2 0 . 1 3}$ \\
\hline UK & 25.75 & 26.95 & 27.61 & 29.09 & 31.02 & $\mathbf{2 8 . 1 7}$ \\
\hline Average & $\mathbf{1 9 . 5 8}$ & $\mathbf{2 1 . 5 0}$ & $\mathbf{2 1 . 4 7}$ & $\mathbf{2 2 . 6 4}$ & $\mathbf{2 4 . 1 2}$ & $\mathbf{2 1 . 9 5}$ \\
\hline
\end{tabular}

We computed per country and per year the average company corporate governance ratings based on the ratings developed by Deminor Rating for the FTSE Eurotop 300 companies. Deminor scores the companies on the basis of a grid consisting of over 300 corporate governance criteria. The maximum score obtainable is 40 .

Table 5: Country score on corporate governance recommendations per year

\begin{tabular}{lrrrrrr}
\hline & $\mathbf{1 9 9 9}$ & $\mathbf{2 0 0 0}$ & $\mathbf{2 0 0 1}$ & $\mathbf{2 0 0 2}$ & $\mathbf{2 0 0 3}$ & Average \\
\hline Austria & 0.00 & 0.00 & 0.00 & 35.00 & 35.00 & $\mathbf{7 . 0 0}$ \\
\hline Belgium & 29.25 & 29.25 & 29.25 & 30.25 & 30.25 & $\mathbf{2 9 . 6 5}$ \\
\hline Denmark & 0.00 & 16.50 & 28.00 & 28.00 & 31.00 & $\mathbf{2 5 . 8 8}$ \\
\hline Finland & 15.00 & 18.25 & 18.25 & 18.25 & 35.00 & $\mathbf{2 0 . 9 5}$ \\
\hline France & 28.00 & 28.00 & 28.00 & 35.50 & 35.50 & $\mathbf{3 1 . 0 0}$ \\
\hline Germany & 0.00 & 28.50 & 28.50 & 41.50 & 41.50 & $\mathbf{2 8 . 0 0}$ \\
\hline Greece & 31.25 & 31.25 & 33.75 & 34.75 & 34.75 & $\mathbf{3 3 . 1 5}$ \\
\hline Ireland & 23.25 & 23.25 & 23.25 & 23.25 & 23.25 & $\mathbf{2 3 . 2 5}$ \\
\hline Italy & 23.00 & 23.00 & 23.00 & 33.75 & 33.75 & $\mathbf{2 7 . 3 0}$ \\
\hline Netherlands & 16.00 & 16.00 & 20.00 & 20.00 & 35.00 & $\mathbf{2 1 . 4 0}$ \\
\hline Portugal & 20.00 & 20.00 & 23.00 & 25.25 & 25.25 & $\mathbf{2 2 . 7 0}$ \\
\hline Spain & 23.25 & 23.25 & 23.25 & 23.25 & 33.25 & $\mathbf{2 5 . 2 5}$ \\
\hline Sweden & 20.50 & 20.50 & 31.00 & 31.00 & 31.00 & $\mathbf{2 6 . 8 0}$ \\
\hline UK & 35.50 & 36.50 & 36.50 & 35.60 & 44.00 & $\mathbf{3 7 . 6 2}$ \\
\hline Average & $\mathbf{1 8 . 9 3}$ & $\mathbf{2 2 . 4 5}$ & $\mathbf{2 4 . 7 0}$ & $\mathbf{2 9 . 6 7}$ & $\mathbf{3 3 . 4 6}$ & $\mathbf{2 5 . 8 4}$ \\
\hline
\end{tabular}

The country scores are developed on the basis of a corporate governance index consisting of 48 principles gathered from the OECD principles of corporate governance (1999). Each country is scored on the inclusion of these principles in its corporate governance codes at the beginning of each year. The scores are summed up to arrive at a total score per country and per year. The maximum score is 48 . 
Table 6: OLS regressions without controlling for selection bias and endogeneity Performance $_{i t}=\alpha+\beta_{1}$ CGFIRM $_{i t}+\beta_{2}$ LNMV $_{\text {it }}+\beta_{3}$ LNAGE $_{i t}+\beta_{4}$ SALESGR $_{i t}+\beta_{5}$ LEVERAGE $_{i t}+\beta_{6}$ OWNCONC $_{i t}+\beta_{7}$ CAPINT $_{\text {it }}$ $+\beta_{8}$ LOSS $_{\mathrm{it}}+\beta_{9}$ ACCSTAND $_{\mathrm{it}}+\sum \beta_{\mathrm{t}}$ TIME EFFECTS $_{\mathrm{t}}+\sum \beta_{\mathrm{k}}$ INDUSTRY EFFECTS $_{\mathrm{k}}+\varepsilon_{\mathrm{it}}$

\begin{tabular}{|c|c|c|c|c|c|c|c|c|c|c|}
\hline & \multicolumn{2}{|c|}{$\mathbf{Q}$} & \multicolumn{2}{|c|}{ MTS } & \multicolumn{2}{|c|}{ MTBV } & \multicolumn{2}{|c|}{ ROA } & \multicolumn{2}{|c|}{ ROE } \\
\hline & coeff & $\mathrm{p}$-value & coeff & p-value & coeff & $\mathrm{p}$-value & coeff & p-value & coeff & $\mathrm{p}$-value \\
\hline Cons & -1.180 & 0.554 & 1.633 & 0.545 & -3.637 & 0.366 & -0.030 & 0.552 & -0.102 & 0.362 \\
\hline CGFIRM & 0.013 & 0.777 & 0.026 & 0.129 & 0.019 & 0.585 & -0.000 & 0.816 & -0.001 & 0.832 \\
\hline LNMV & 0.195 & $0.085^{*}$ & 0.168 & 0.259 & 0.348 & 0.100 & 0.004 & 0.178 & 0.007 & 0.223 \\
\hline LNAGE & -0.307 & $0.078^{*}$ & -0.610 & $0.064^{*}$ & -0.235 & 0.451 & 0.016 & 0.063 & 0.014 & $0.070^{*}$ \\
\hline SALESGR & 0.847 & $0.084^{*}$ & 1.180 & $0.067^{*}$ & 0.677 & 0.474 & 0.057 & $0.072^{*}$ & 0.041 & $0.042^{*}$ \\
\hline LEVERAGE & -0.084 & $0.000^{* * *}$ & -0.177 & $0.000^{* * *}$ & -0.108 & $0.056^{*}$ & -0.003 & $0.000^{* * *}$ & -0.002 & 0.422 \\
\hline OWNCONC & 0.139 & 0.717 & -0.774 & 0.451 & 0.531 & 0.535 & -0.013 & 0.567 & 0.022 & 0.372 \\
\hline CAPINT & -1.049 & $0.053^{*}$ & -2.325 & $0.025^{* *}$ & -2.977 & $0.004^{* * *}$ & -0.004 & 0.842 & -0.026 & 0.371 \\
\hline LOSS & -0.446 & $0.022^{* *}$ & -0.073 & 0.902 & -0.572 & 0.212 & -0.143 & $0.000^{* * *}$ & -0.425 & $0.000^{* * *}$ \\
\hline ACCSTAND & -0.106 & 0.556 & -0.246 & 0.345 & -0.430 & 0.294 & 0.001 & 0.835 & 0.013 & 0.265 \\
\hline $\mathbf{R}^{2}$ & \multicolumn{2}{|c|}{0.115} & \multicolumn{2}{|c|}{0.089} & \multicolumn{2}{|c|}{0.110} & \multicolumn{2}{|c|}{0.197} & \multicolumn{2}{|c|}{0.186} \\
\hline
\end{tabular}

This table presents results from OLS regressions of performance measures (Q, MTS, MTBV, ROA, ROE) on company corporate governance ratings and control variables. All variables are defined in Table 1. Regressions are estimated for the pooled sample (1999-2003) with year and industry effects (not reported). Standard errors are heteroskedasticity robust, clustered at the firm level. Two-tailed tests are used. The sample used is the FTSE Eurotop 300 sample (1,199 observations, see Table 2).

Significant at the $1 \%$ level. ${ }^{* *}$ Significant at the $5 \%$ level. ${ }^{*}$ Significant at the $10 \%$ level. 
Table 7: Comparison of means of total population with FTSE Eurotop 300 companies

\begin{tabular}{lccc}
\hline & Population & FTSE Eurotop 300 & t-test $^{\text {a }}$ \\
\hline Q & 1.822 & 1.965 & $2.411^{* * * *}$ \\
\hline MTS & 2.150 & 3.004 & $5.148^{* * *}$ \\
\hline MTBV & 3.063 & 3.693 & $4.660^{* * *}$ \\
\hline ROA & -0.008 & 0.057 & $17.995^{* * *}$ \\
\hline LNMV & -0.081 & 0.128 & $24.521^{* * *}$ \\
\hline LNAGE & 11.664 & 16.350 & $127.996^{* * *}$ \\
\hline SALESGR & 2.102 & 2.759 & $24.849^{* * * *}$ \\
\hline LEVERAGE & 0.245 & 0.115 & $-14.417^{* * *}$ \\
\hline OWNCONC & 1.303 & 2.642 & $10.183^{* * *}$ \\
\hline CAPINT & 0.324 & 0.213 & $-16.043^{* * *}$ \\
\hline LOSS & 0.262 & 0.263 & 0.145 \\
\hline ACCSTAND & 0.281 & 0.081 & $-24.417^{* * *}$ \\
\hline LISTING & 0.050 & 0.057 & 1.033 \\
\hline PERCIA & 1.091 & 2.049 & $17.187^{* * * *}$ \\
\hline GDP & 0.114 & 0.147 & $6.386^{* * *}$ \\
\hline MARKCAP & 10.003 & 10.019 & $7.906^{* * *}$ \\
\hline & 103.179 & 104.062 & 1.847 \\
\hline
\end{tabular}

${ }^{* * *}$ Significantly different at less than the $1 \%$ level.

Table 8: Stage 1 selection equation

PROBIT $\left(\right.$ RATING $\left._{\mathrm{it}}\right)=\alpha+\beta_{1}$ LNMV $_{\mathrm{it}}+\beta_{2}$ LNAGE $_{\mathrm{it}}+\beta_{3}$ SALESGR $_{\mathrm{it}}+\beta_{4}$ LEVERAGE $_{\mathrm{it}}+\beta_{5}$ OWNCONC $_{\text {it }}$

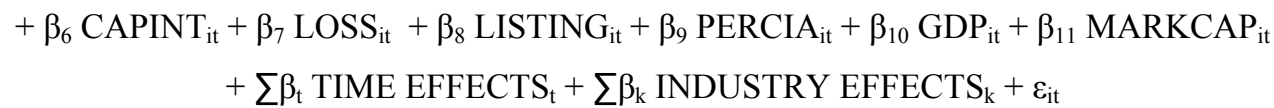

\begin{tabular}{lcl}
\hline & Coeff & P-value \\
\hline Cons & -3.140 & 0.011 \\
\hline LNMV & 0.935 & $0.000^{* * *}$ \\
\hline LNAGE & 0.247 & $0.000^{* * *}$ \\
\hline SALESGR & -0.146 & $0.038^{* *}$ \\
\hline LEVERAGE & 0.015 & $0.008^{* * *}$ \\
\hline OWNCONC & -0.864 & $0.000^{* * *}$ \\
\hline CAPINT & 0.029 & 0.837 \\
\hline LOSS & -0.043 & 0.674 \\
\hline ACCSTAND & -0.008 & 0.945 \\
\hline LISTING & 0.160 & $0.000^{* * *}$ \\
\hline PERCIA & 0.396 & $0.000^{* * *}$ \\
\hline GDP & 0.309 & $0.000^{* * *}$ \\
\hline MARKCAP & 0.008 & $0.000^{* * *}$ \\
\hline Pseudo R & \multicolumn{2}{c}{0.696} \\
\hline
\end{tabular}

This table presents results from a regression where the dependent variable indicates whether or not the company has a corporate governance rating. The independent variables are all defined in Table 1 . The regression is estimated for the pooled sample of the total population of listed companies (33,667 observations, see Table 3) with year and industry effects (not reported). Probit estimation is used. Standard errors are heteroskedasticity robust, clustered at the firm level. Two-tailed tests are used.

***Significant at the $1 \%$ level. **Significant at the $5 \%$ level. 
Table 9: Stage 2 reduced-form equation

$$
\begin{gathered}
\text { CGFIRM }_{\mathrm{it}}=\alpha+\beta_{1} \text { CGFIRM }_{\mathrm{it}-1}+\beta_{2} \text { CGCOUNTRY }_{\mathrm{it}}+\beta_{3} \text { LNMV }_{\mathrm{it}}+\beta_{4} \text { LNAGE }_{\mathrm{it}}+\beta_{5} \text { SALESGR }_{\mathrm{it}}+\beta_{6} \\
\text { LEVERAGE }_{\mathrm{it}}+\beta_{7} \text { OWNCONC }_{\mathrm{it}}+\beta_{8} \text { CAPINT }_{\mathrm{it}}+\beta_{9} \text { LOSS }_{\mathrm{it}}+\beta_{10} \text { ACCSTAND }_{\mathrm{it}}+\beta_{11} \text { MILLS }_{\mathrm{it}}+\sum \beta_{\mathrm{t}} \text { TIME } \\
\text { EFFECTS }_{\mathrm{t}}+\sum \beta_{\mathrm{k}} \text { INDUSTRY EFFECTS }_{\mathrm{k}}+\varepsilon_{\mathrm{it}}
\end{gathered}
$$

\begin{tabular}{lcl}
\hline & Coeff & P-value \\
\hline Cons & 4.026 & 0.197 \\
\hline CGFIRMt-1 & 0.821 & $0.000^{* * *}$ \\
\hline CGCOUNTRY & 0.067 & $0.001^{* * *}$ \\
\hline LNMV & 0.016 & 0.921 \\
\hline LNAGE & -0.219 & 0.168 \\
\hline SALESGR & 0.134 & $0.049^{* *}$ \\
\hline LEVERAGE & -0.008 & 0.812 \\
\hline OWNCONC & -2.680 & $0.000^{* * *}$ \\
\hline CAPINT & 0.951 & $0.041^{* *}$ \\
\hline LOSS & -0.165 & 0.517 \\
\hline ACCSTAND & 0.289 & 0.410 \\
\hline MILLS & 0.023 & 0.967 \\
\hline R $^{2}$ & 0.831 \\
\hline partial R & \multicolumn{2}{c}{0.791} \\
\hline F-test & 1088.1 & $0.000^{* * *}$ \\
\hline
\end{tabular}

This table presents results from a regression of the corporate governance ratings $\left(\mathrm{CGFIRM}_{\mathrm{it}}\right)$ on a number of instruments $\left(\right.$ CGFIRM $_{\mathrm{it}-1}, \mathrm{CGCOUNTRY}_{\text {it }}$ ), the inverse Mills ratio, and control variables (all defined in Table 1). The regression is estimated for the pooled sample of FTSE Eurotop 300 companies (1199 observations, see Table 2) with year and industry fixed effects (not reported). Standard errors are heteroskedasticity robust, clustered at the firm level. Two-tailed tests are used. The partial $\mathrm{R}^{2}$ of the instruments is computed and an F-test is performed on the coefficients of the instruments.

***Significant at the $1 \%$ level. **Significant at the $5 \%$ level. *Significant at the $10 \%$ level. 
Table 10: Stage 3 structural equation

Performance $_{i t}=\alpha+\beta_{1}$ CGFIRM estimated $_{i t}+\beta_{2}$ LNMV $_{i \mathrm{t}}+\beta_{3}$ LNAGE $_{\mathrm{it}}+\beta_{4}$ SALESGR $_{\mathrm{it}}+\beta_{5}$ LEVERAGE $_{\mathrm{it}}+\beta_{6}$ OWNCONC $_{\mathrm{it}}+\beta_{7}$ CAPINT $_{\text {it }}+\beta_{8}$ LOSS $_{\mathrm{it}}+\beta_{9}$ ACCSTAND $_{i t}+\beta_{10}$ MILLS $_{\text {it }}+\sum \beta_{\mathrm{t}}$ TIME EFFECTS $_{\mathrm{t}}+\sum \beta_{\mathrm{k}}$ INDUSTRY EFFECTS $_{\mathrm{k}}+\varepsilon_{\mathrm{it}}$

\begin{tabular}{|c|c|c|c|c|c|c|c|c|c|c|}
\hline & \multicolumn{2}{|c|}{$\mathbf{Q}$} & \multicolumn{2}{|c|}{ MTS } & \multicolumn{2}{|c|}{ MTBV } & \multicolumn{2}{|c|}{ ROA } & \multicolumn{2}{|c|}{ ROE } \\
\hline & Coeff & P-value & Coeff & P-value & Coeff & P-value & Coeff & P-value & Coeff & P-value \\
\hline Cons & -4.994 & 0.178 & -4.860 & 0.537 & -5.178 & 0.060 & -0.208 & 0.041 & -0.149 & 0.032 \\
\hline CGFIRM estimated & 0.076 & $0.001^{* * *}$ & 0.097 & $0.009^{* * *}$ & 0.206 & $0.030^{* *}$ & 0.012 & $0.005^{* * *}$ & 0.018 & $0.002^{* * *}$ \\
\hline LNMV & 0.378 & $0.000^{* * *}$ & 0.512 & $0.021^{* *}$ & 0.789 & $0.066^{*}$ & 0.013 & $0.015^{* *}$ & 0.042 & $0.016^{* *}$ \\
\hline LNAGE & -0.208 & $0.073^{*}$ & -0.693 & $0.035^{* *}$ & -0.049 & 0.886 & 0.013 & $0.061^{*}$ & 0.031 & $0.026^{* *}$ \\
\hline SALESGR & 0.819 & $0.089^{*}$ & 1.148 & $0.081^{*}$ & 1.548 & 0.106 & 0.079 & $0.002^{* * *}$ & 0.016 & $0.066^{*}$ \\
\hline LEVERAGE & -0.077 & $0.000^{* * *}$ & -0.166 & $0.000^{* * *}$ & -0.085 & 0.117 & -0.002 & $0.006^{* * *}$ & -0.002 & 0.369 \\
\hline OWNCONC & 0.067 & 0.924 & -1.057 & 0.216 & 1.392 & 0.395 & -0.007 & 0.641 & -0.018 & 0.535 \\
\hline CAPINT & -1.078 & $0.029^{* *}$ & -2.210 & $0.027^{* *}$ & -3.286 & $0.001^{* * *}$ & 0.061 & $0.000^{* * *}$ & -0.005 & 0.890 \\
\hline LOSS & -0.463 & $0.015^{* *}$ & -0.043 & 0.942 & -0.670 & 0.174 & -0.122 & $0.000^{* * *}$ & -0.422 & $0.000^{* * *}$ \\
\hline ACCSTAND & -0.088 & 0.604 & -0.205 & 0.418 & -0.412 & 0.337 & -0.002 & 0.752 & -0.023 & 0.152 \\
\hline MILLS & 0.501 & $0.023^{* *}$ & 0.922 & $0.022^{* *}$ & 1.021 & $0.027^{* *}$ & 0.021 & $0.081^{*}$ & 0.083 & $0.026^{* *}$ \\
\hline $\mathbf{R}^{2}$ & \multicolumn{2}{|c|}{0.133} & \multicolumn{2}{|c|}{0.091} & \multicolumn{2}{|c|}{0.131} & \multicolumn{2}{|c|}{0.212} & \multicolumn{2}{|c|}{0.193} \\
\hline Hausman $^{a}$ & \multicolumn{2}{|c|}{$0.051^{*}$} & \multicolumn{2}{|c|}{$0.064^{*}$} & \multicolumn{2}{|c|}{$0.052^{*}$} & \multicolumn{2}{|c|}{$0.044^{* *}$} & \multicolumn{2}{|c|}{$0.053^{*}$} \\
\hline
\end{tabular}

This table presents results from regressions of performance measures on the estimated corporate governance rating from stage 2 (CGFIRM estimated ${ }_{i t}$, calculated from Table 9), the inverse Mills ratio, and a number control variables (all defined in Table 1). The regression is estimated for the pooled sample of FTSE Eurotop 300 companies (1199 observations, see Table 2) with year and industry fixed effects. Standard errors are heteroskedasticity robust, clustered at the firm level. Two-tailed tests are used.

***Significant at the $1 \%$ level. **Significant at the $5 \%$ level. *Significant at the $10 \%$ level.

${ }^{a}$ Hausman gives the coefficient of the estimated corporate governance ratings (CGFIRM estimated $\mathrm{d}_{\mathrm{i}}$ ) calculated from stage 2 of the following OLS regression:

Performance $_{\text {it }}=\alpha+\beta_{1}$ CGFIRM estimated $_{i t}+\beta_{2}$ CGFIRM $_{\text {it }}+\beta_{3}$ LNMV $_{\text {it }}+\beta_{4}$ LNAGE $_{\text {it }}+\beta_{5}$ SALESGR $_{\text {it }}+\beta_{6}$ LEVERAGE $_{\text {it }}+\beta_{7}$ OWNCONC $_{\text {it }}+\beta_{8}$ CAPINT $_{\text {it }}+\beta_{9}$ LOSS $_{\text {it }}+$ $\beta_{10}$ ACCSTAND $_{\text {it }}+\beta_{10}$ MILLS $_{\text {it }}+\sum \beta_{\mathrm{t}}$ TIME EFFECTS $_{\mathrm{t}}+\sum \beta_{\mathrm{k}}$ INDUSTRY EFFECTS $_{\mathrm{k}}+\varepsilon_{\mathrm{it}}$ 
Table 11: Step by Step approach

\begin{tabular}{lcccc}
\hline & $\begin{array}{c}\mathbf{( 1 )} \\
\text { OLS }\end{array}$ & $\begin{array}{c}\mathbf{( 2 )} \\
\text { SSB } \\
\text { (Heckman) }\end{array}$ & $\begin{array}{c}\mathbf{( 3 )} \\
\text { Endogeneity } \\
\text { (2SLS) }\end{array}$ & $\begin{array}{c}\text { 3-stage } \\
\text { model }\end{array}$ \\
\hline Q & 0.013 & 0.033 & 0.041 & 0.076 \\
& $(0.777)$ & $(0.093)$ & $(0.070)$ & $(0.001)$ \\
\hline MTS & 0.025 & 0.045 & 0.065 & 0.097 \\
& $(0.129)$ & $(0.052)$ & $(0.019)$ & $(0.009)$ \\
\hline MTBV & 0.019 & 0.076 & 0.098 & 0.206 \\
& $(0.585)$ & $(0.124)$ & $(0.082)$ & $(0.030)$ \\
\hline ROA & -0.000 & 0.000 & 0.001 & 0.012 \\
& $(0.816)$ & $(0.874)$ & $(0.362)$ & $(0.005)$ \\
\hline ROE & -0.001 & 0.002 & 0.001 & 0.018 \\
& $(0.852)$ & $(0.739)$ & $(0.926)$ & $(0.002)$ \\
\hline
\end{tabular}

This table presents the coefficient and p-value (between brackets) of corporate governance for each performance measure under OLS estimation (i.e. without controlling for either sample selection bias or endogeneity), after controlling for sample selection bias through a Heckman two-stage approach, after controlling for endogeneity through the use of 2SLS, and after controlling for both sample selection bias and endogeneity based on the three-stage model.

The first column presents the results from OLS regressions without controlling for sample selection bias and endogeneity.

The second column shows the results after controlling for sample selection bias. This is done by use of the Heckman (1979) procedure. In a first stage, we estimate the probability of being in the sample in function of a number of explanatory variables. In the second stage, we regress performance on corporate governance, the inverse Mills ratio from the first stage and a number of control variables.

In the third column, we control for the endogeneity problem by using $2 \mathrm{SLS}$. In a first stage we regress corporate governance on the instruments (CGFIRM t $_{-1}$ \& CGCOUNTRY) and a number of control variables. In the second stage we regress performance on the estimated corporate governance from the first stage and a number of control variables.

The fourth column presents the results of our 3-stage model in which we control simultaneously for sample selection bias and endogeneity. 